\title{
Impact of Job Stress on Job Attitudes and Life Satisfaction in College Lecturers
}

\author{
Ejaz Ahmed Khan, Muhammad Aqeel, and Muhammad Akram Riaz
}

\begin{abstract}
The main objective of this study was to find out the relationship of job stress with job attitudes in college lecturers. This is a cross-sectional study design based on purposive sampling technique. The results revealed that job stress has a significant negative relationship with job performance, job satisfaction, and life satisfaction while positively significant related with turnover intentions. Further a significant difference was found among married and unmarried college lecturers on these study variables.
\end{abstract}

Index Terms-Job stress, job performance, job satisfaction, life-satisfaction.

\section{INTRODUCTION}

The unpleasant condition or position at work place which negatively influence on an individual's overall well-being and performance is known as job stress. Due to these unwanted settings, a person suffers from physical and mental illnesses. Job stress is not a new phenomenon of the present day. The term stress is coined with the Selye and it is the general psychological and physiological reaction of the body to any event or stressor [1]. There are many types of stressors like noise and dim light at working place, high job demands, role overload, role ambiguity, lack of sleep and time pressure. These variables can lead to high job stress which can cause poor health and dissatisfaction with the job attitudes [2]. Job stress varies from general stress. Job stress is a confrontational response to the job descriptions of employees [3]. "Reference [4] labeled job stress as a work related psychological pressure and a worker's ability to respond and grip the specific situation at work place skillfully". Many previous studies investigated that the escalation in workload and long working hours also provide the base of occupational stress among the academicians [5], [6]. The job demands of the teaching profession as researchers, administrators and supervisors also increase job related stress among teachers of higher education [7]. Due the rapid changes in higher education structure, the academicians also supposed to perceive a considerable increase in the executive responsibilities which cause psychological problems [8].

There are many individual differences and abilities among the teaching staff which lead them to emotional and psychological worries. The main factors of this state are excessive research work, shortage of time and energy as well as over loads of teaching the extra classes [9]. In particular several researches described that increasing professional responsibilities are the most important elements that

Manuscript received August 17, 2013; revised November 20, 2013.

Ejaz Ahmed Khan is with the International Islamic University Islamabad Pakistan, Pakistan (e-mail: ejaz_psychologist@yahoo.com). contribute their share in prevailing the psychological and emotional problems and poor job performance [10], [11]. There are many personal differences, inter and intra personal conflicts among the teaching staff, everyday work load, contradictory demands from colleagues and seniors, uneven demands from their different personal and organizational roles, insufficient resources for suitable presentation, unsatisfactory proficiency to meet the demands of their job, poor self-sufficiency to make decision on different tasks became the main basis of job related stressors [12], [13].

\section{LITERATURE REVIEW}

It was evidenced in the past studies that jab stress deposited adverse relationship on job attitudes, self-confidence, dissatisfaction with life and the upswing in turnover intentions [14]-[16]. Job stress is an outcome of many psychosocial factors which affect the workforce in irregular ways. "Reference [17] described that there is an undesirable correlation between job stress and job performance". A famous study of the faculty members of a medical college also established these results across the gender [18]. Stress is connected to some psychological problems i.e. anxiety, low self-esteem and motivation, mood variations. These consequences decline the job performance; job satisfaction and climbing the turnover intentions severely without gender regard [19]. The subject of turnover intentions has been deeply rooted history and remarkable reputation among researchers, consultants and academicians around the world. "Reference [20] defined the turnover intentions as it is a rational and measured attitude towards leaving a job. Many studies in the past pointed out that turnover intention forecasts the turnover precisely [21], [22]. Job stress has broad consequences on turnover intentions. The high amount of stress leads to dissatisfaction with the job and low job performance. This deprived situation provides a favorable environment for turnover intention among the employees. Finally they leave the job and find a better opportunity [23], [24].

"Reference [25] described the term job satisfaction as it is a stable and balanced arrangement of environmental, psychological and physiological situations at work place. Due to this refine linkage of these features an individual enforced to say that I am satisfied with my job." Job satisfaction depends upon the optimistic feelings of employees towards their jobs [26]. Job satisfaction is observed as the feelings experienced by an individual after the completion of a task or job. This mental or psychological state could be positive or negative and primarily conditioned with the outcome of that completed the job [27]. "Reference [28] conducted a study on health workers and established the negative relationship among job stress, job satisfaction and 
job performance. Another research revealed the negative significant association with job satisfaction and poor physical health, low psychological well-being and high level of job stress [29].

"Reference [30] defined that stress is the key component and have positive significant correlation with high turnover and turnover intentions, absenteeism and costs substantial health problems. These researchers also established the negative significant relation to decreased job performance, job satisfaction and low level of satisfaction with life". Numerous past researches also highlighted the significant link between stress and its contrary reactions such as sleep disorders, psychological problems, heart disease and low level of job performance, job satisfaction, rising turnover intentions and low standard of satisfaction with life [31]-[33].

\section{A. Purpose of the Study}

From the last three decades stress is a topic of wide-ranging attention to industrial and organizational scholars, managing experts, and human resource administrators. Keeping in mind the importance of this bubbly and fizzing issue this current study has following objectives:

1) The primary objective was to inspect the association of job stress with job performance, job satisfaction, turnover intentions and life satisfaction among the college lecturers.

2) The second objective was to estimate the level of all study variables between married and unmarried college lecturers.

\section{B. Hypotheses}

From the extensive literature review we formulated these hypotheses as under:

- H1: There is negative relationship of job stress with job performance, job and life satisfaction among collage lecturers.

- H2: There is positive relationship between job stress and turnover intentions among collage lecturers.

- H3: Unmarried lecturers are high on job stress and turnover intentions.

\section{METHOD}

\section{A. Participants}

The participants were comprised on teaching community and the sample covered only one hundred and forty college lecturers $(N=140)$ equal male $(n=70)$ and female $(n=70)$ from different public higher educational colleges of Faisalabad division Pakistan. For the purpose of data collection we applied purposive sampling method.

\section{B. Instruments}

The participants were requested to complete a set of questionnaires according to their agreement and disagreement with all statements. For the measurement of job stress the Job Stress Questionnaire, JSQ [34] was used. The Alpha Reliability $(\alpha)$ was 0.80 . Job performance was evaluated with six items scale [35]. The reliability $(\alpha)$ of the scale was 0.87 . For the assessment of job satisfaction and turnover intentions we use Michigan Organizational
Assessment Questionnaire "unpublished" [36]. These two scales contained three items each. The Cronbach's Alpha Reliability $(\alpha)$ was 0.88 and 0.82 respectively in our study. For assessing the life satisfaction we used Life Satisfaction Scale [37]. This scale has 5 items and the reliability was 0.85 .

\section{Procedure}

This study based on cross-sectional survey design. Before administering the study scales the informed consent was received from the participants and then the researchers informed the participants individually the importance, purpose and implications of this study. All the participants were contacted and approached during their free periods and breaking times. Approval was also got from the principals of the respective colleges for the purpose of data collection. During this data collection process ethical issues were followed on top priorities.

\section{RESUlTS}

The major research question for this current study was sought out the relationship of stress among job outcome and life satisfaction. In order to answer this research question the required statistical analyses were computed for the results. The results are presented as under (See Table I):

TABLE I: THE DESCRIPTIVE STATISTICS, ALPHA RELIABILITY AND

\begin{tabular}{|c|c|c|c|c|c|c|c|c|}
\hline Variables & M & SD & $\alpha$ & 1 & 2 & 3 & 4 & 5 \\
\hline JS & 18.76 & 5.11 & .80 & - & $-.18^{*}$ & $.54^{* *}$ & $-.41^{* *}$ & $-.45^{* *}$ \\
& & & & & & & & \\
\hline JP & 3.89 & .87 & .87 & & - & $-.28^{* *}$ & $.49^{* *}$ & .16 \\
\hline TI & 8.22 & 3.62 & .82 & & & - & $-.56^{* *}$ & $-.53^{* *}$ \\
\hline JS & 22.24 & 4.23 & .88 & & & & - & $.34^{* *}$ \\
\hline LS & 7.05 & 1.38 & .85 & & & & & - \\
\hline
\end{tabular}

Note: JS (Job Stress), JP (Job Performance), TI (Turnover Intentions), JS (Job Satisfaction), LS (Life Satisfaction).

This table revealed that job stress was significant associated with job performance $(r=-.18, P<.05)$, turnover intentions $(r=.54, P<.01)$, job satisfaction $(r=-.41, P<.01)$, and life satisfaction $(r=.45, P<.01)$. Job performance was significant correlated with, turnover intentions $(r=-.28, P$ $<.01)$, job satisfaction $(r=.49, P<.01)$ whereas life satisfaction was non-significant correlated $(r=.16)$. Turnover intentions was significant correlated with job satisfaction $(r=$ $-.56, P<.01)$ and life satisfaction $(r=-.53, P<.01)$. Job satisfaction was significant with life satisfaction $(r=.34, \mathrm{P}$ $<.01)$

Table II revealed that stress was significant predictor for job performance $\left(\beta=-.18^{*}, \Delta R 2=.024, F=3.18^{*}\right)$, turnover intention $\left(\beta=.54 * * *, \Delta R 2=.201, F=36.18^{* * *}\right)$, job satisfaction $(\beta=-.41 * * *, \Delta R 2=.158, F=17.73 * * *)$, and life satisfaction $\left(\beta=-.45^{* * *}, \Delta R 2=.201, F=23.35^{*}\right)$. This model explained that if stress is higher than job performance, job satisfaction, and life satisfaction will be reduced while turnover intention will be high among lecturers. 
TABLE II: LINEAR REGRESSION ANALYSIS

\begin{tabular}{|c|c|c|c|c|c|c|c|c|c|c|c|c|}
\hline & \multicolumn{3}{|c|}{$\mathrm{JP}$} & \multicolumn{3}{|c|}{ TI } & \multicolumn{3}{|c|}{ JS } & \multicolumn{3}{|c|}{$\mathrm{LS}$} \\
\hline Model & $\beta$ & $\Delta R^{2}$ & $F$ & $B$ & $\Delta R^{2}$ & $F$ & $\beta$ & $\Delta R^{2}$ & $F$ & $\beta$ & $\Delta R^{2}$ & $F$ \\
\hline JS & $-18 *$ & .024 & $3.18 *$ & $.54 * * *$ & .201 & $36.18 * * *$ & $-.41 * * *$ & .158 & $17.73^{* * *}$ & $-.45 * * *$ & .201 & $23.35 * * *$ \\
\hline
\end{tabular}

TABLE III: MEAN, STANDARD DEVIATION AND T-VALUE

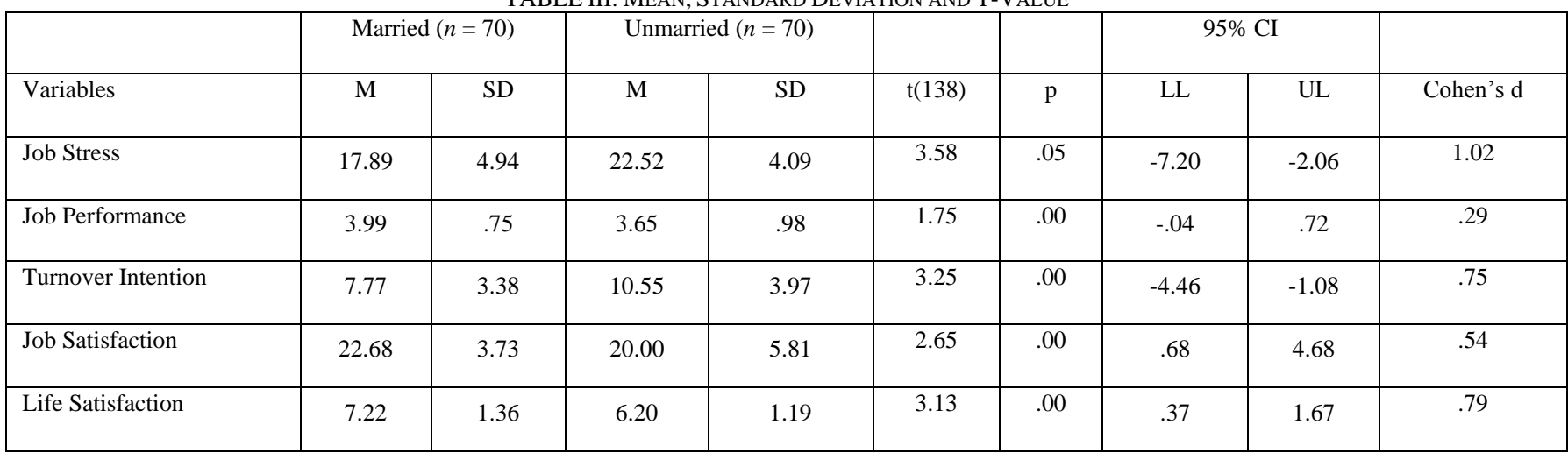

Table III revealed that stress and turnover intentions were significant higher among unmarried lecturers than married lecturers. The results shown in same table that job performance, job satisfaction and life satisfaction was higher among married lecturers as compare to unmarried lecturers. The Cohen's d showed that stress and turnover intentions was highly correlated among unmarried lecturers as compare to married lecturers while job performance, job satisfaction and life satisfaction were moderately correlated among married and unmarried lecturers.

\section{DISCUSSION}

The results of this study exposed the negative relationship of job stress with job performance, job satisfaction, and life satisfaction. However, stress has a positive significant relationship with turnover intentions among lecturers. The findings also pointed out that the level of stress and turnover intentions in unmarried lecturers is high as compare to married lecturers. The hypotheses of this study are sustained by the results. These findings are constant with the prior researches too. According to the results of previous investigations job stress has negative significant association with job performance [38], [39], life satisfaction, job satisfaction and turnover intentions [40]-[42]. Due to job stress the job performance and job satisfaction decreases and the turnover intentions increases [43]. Various previous studies also verified that employees who face unusual high job stress have low levels of job performance, job satisfaction and life satisfaction. Ultimately this state of dissatisfaction leads to high turnover intentions. Unmarried employees showed high job stress as compared to married employees due to poor peer relations and low social support from the family members [44]. "Reference [45] explained that unmarried and young employees have low levels of job performance, job satisfaction, low level of satisfaction with life and high turnover intentions as compared to married and older workers. The results of this current study proved with the previous studies and have strong support from their findings.

\section{LIMITATIONS AND SUGGESTIONS}

The current study also incorporated with some limitations. Due the shortage of time and resources we only approached a small sample of the vast population. This factor can raise the question of the generalizability. To avoid this issue the sample would be increased in upcoming researches. This study also carries the road map for future research in wide organizational and administrative perspective. Later studies can comprehend the other variables in large and comparative sample with the present variables to enhance the generalizability and reliability of the findings. The sampling technique using for data collection in this study could be improved in future by adopting the random sampling technique.

\section{REFERENCES}

[1] H. Selye, "A syndrome produced by diverse noxious agents," Nature, vol. 138 , pp. 32-35, July 1936

[2] H. Selye, The Stress of Life, New York: McGraw-Hill, 1956.

[3] J. A. Waters and W. Ussery, "Police stress: History, contributing factors, symptoms, and interventions. Policing," An International Journal of Police Strategies and Management, vol. 30, no. 2, pp. 169-188, April 2007.

[4] J. C. Chen and C. Silverthorne, "The impact of locus of control on job stress, job performance and job satisfaction in Taiwan," Leadership \& Organization Development Journal, vol. 29, no. 7, pp. 572-582, 2008.

[5] J. Bradley and P. Eachus, "Occupational stress within a U.K. Higher Education Institution," International Journal of Stress Management, vol. 2, no. 3, pp. 145-158, July 1995.

[6] L. Meng and S. Liu, "Mathematics teacher stress in Chinese secondary schools," Journal of Educational Enquiry, vol. 8, no. 1, pp. 73-96, 2008.

[7] S. Fisher, Stress in Academic Life, Buckingham, UK: The Society for Research in to Higher Education and Open University Press, 1994.

[8] S. M. Azeem and N. A. Nazir, "A study of job burnout among university teachers," Psychology and Developing Societies, vol. 20, no. 1, pp. 51-64, Jan. 2008. 
[9] C. Thompson and E. Dey, "Pushed to the margins: Sources of stress for Africa American college and university faculty," Journal of Higher Education, vol. 69, no. 3, pp. 324-345, May-June 1998.

[10] C. Cooper and J. Roden, "Mental health and satisfaction among tax officers," Social Science and Medicine, vol. 21, no. 7, pp. 747-751, 1985.

[11] M. Westman and D. Eden, "Excessive role demand and subsequent performance," Journal of Organizational Behavior, vol. 13, no. 5, pp. 519-529, Sep. 1992.

[12] J. Mearns and J. E. Cain, "Relationships between teachers' occupational stress and their burnout and distress: Roles of coping and negative mood regulation expectancies," Anxiety, Stress, and Coping, vol. 16, no. 1, pp. 71-82, Mar. 2003.

[13] S. Ahmady T. Changiz, M. Italo, and M. Brommeis, "Organizational role stress among medical school faculty members in Iran: Dealing with role conflict," BMC Medical Education, vol. 7, pp. 14-19, Apr. 2007.

[14] J. R. P. French and R. D, Caplan, "Psychological factors in coronary heart disease," Industrial Medicine, vol. 39, pp. 383-397, 1970.

[15] V. Austin, S. Shah, and S. Muncer, "Teacher stress and coping strategies used to reduce stress," Occupational Therapy International, vol. 12 , no. 2, pp. 63-80, May 2005

[16] P. Robbins, Organizational Change and Stress Management, Organizational Behavior, 8th Edition, Prentice Hall of India, New Delhi-110.001. 2004, pp. 653.

[17] F. M. Dollard and J. C. Metzer, "Psychological research, practice, and production: The occupational stress problem," International Journal of Stress Management, vol. 6, no. 4, pp. 241-253, Oct. 1999.

[18] A. Soleiman, C. Tahereh, I. Masiello, and M. Brommels, "Organizational role stress among medical school faculty members in Iran: Dealing with role conflict," BMC Medical Education, vol. 7, 14-19, May 2007.

[19] L. Manivannan, M. G. Saravanaraj, and S. Sumathi, "Managing stress among the employees," The ICFAI Journal of Organizational Behavior, vol. 6, no. 2, pp. 53-59, Sep. 2007.

[20] W. H. Mobley, Employee Turnover: Causes, consequences, and Control, Addison: Wesley Publishing Company Inc., 1982.

[21] M. D. Lucas, J. R. Atwood, and R. Hagaman, "replication and validation of anticipated turnover model for urban registered nurses," Nursing Research, vol. 42, no. 1, pp. 29-35, Jan-Feb 1993.

[22] E. Lambert, "To stay or quit: A review of the literature on correctional staff turnover," American Journal of Criminal Justice, vol. 26, no. 1, pp. 61-76, Sep. 2001

[23] J. K. Sager, "A structural model depicting salespeople's job stress," Journal of the Academy of Marketing Science, vol. 22, no. 1, pp. 74-84, Winter, 1994.

[24] D. Fisher and R. Gitelson, "A meta-analysis of the correlates of role conflict and ambiguity," Journal of Applied Psychology, vol. 68, no. 2, pp. 320-333, May 1983.

[25] R. Hoppock, Job Satisfaction, New York, NY: Harper, 1935.

[26] R. E. Spector, Job satisfaction, Application, Assessment, Causes, and Consequences, London: Sage, 1997.

[27] M. Saiyadain, Human Resource Management, New Delhi: Tata McGraw Hill, 2007.

[28] C. Healy and M. McKay, "Identifying sources of stress and job satisfaction in the nursing environment," Australian Journal of Advance Nursing, vol. 17, no. 2, pp. 30-35, Dec. 1989-Feb. 1999.

[29] J. Sheena, C. Cary, C. Sue, D. Ian, T. Paul, and M. Clare, "The experience of work-related stress across occupations," Journal of Managerial Psychology, vol. 20, no. 2, pp. 178-187, March 2005.

[30] R. Abualrub et al., "Job stress, recognition, job performance and intention to stay at work among Jordanian hospital nurses," Journal of Nursing Management, vol. 16, no. 3, pp. 227-236, April 2008.

[31] M. Griffin, "Gender and stress: a comparative assessment of sources of stress among correctional officers," Journal of Contemporary Criminal Justice, vol. 22, no. 1, pp. 4-25, Feb. 2006.

[32] M. Mitoma, R. Yoshimura, A. Sugita, W. Umene, H. Hori, and H. Nakano, "Stress at work alters serum brain-derived neurotropic factor (BDNF) levels and plasma 3-methoxy-4-hydroxyphenylglycol (MHPG) levels in healthy volunteers," Program of Neuro psychopharmacology, Biology and Psychiatry, vol. 32, no. 3, pp. 679-685, Apr. 2008.

[33] Y. Hamidi and Z. Eivaz, "The relationships among employees' job stress, job satisfaction and the organizational performance of Hamadan urban health centers," Social, Behavioral and Personal Psychology, vol. 38, no. 7, pp. 963-968, 2010.
[34] R. D. Caplan, S. Cobb, J. R. P. French, R. V. Harrison, and S. R. Pinneau, "Job demands and worker health," HEW Publication, NIOSH, 1975, pp. 75-160.

[35] L. Williams and S. Anderson, "Job satisfaction and organizational commitment as predictors of organizational citizenship and in-role behaviors," Journal of Management, vol. 17, no. 3, pp. 601-617, Sep. 1991.

[36] C. Cummann, M. Fichman, D. Jenkins, and J. Klesh, The Michigan Organisational Assessment Questionnaire, Unpublished Manuscript, University of Michigan, Ann Arbor, Michigan, 1979.

[37] E. Diener, R. A. Emmons, R. J. Larsen, and S. Griffin, "The satisfaction with life scale," Journal of Personality Assessment, vol. 49, no. 1, pp. 71-75, 1985.

[38] S. E. Jackson and R. S. Schuler, "A meta-analysis and conceptual critique of research on role ambiguity and role conflict in work settings," Organizational Behavior and Human Decision Processes, vol. 36, no. 1, pp. 16-78, Aug. 1985.

[39] M. Westman and D. Eden, "The inverted-U relationship between stress and performance: A field study," Work and Stress, vol. 10, no. 2, pp 165-173, April 1996.

[40] R. A. Karasek, "Job demands, job decision latitude, and mental strain: Implications for job redesign," Administrative Science Quarterly, vol. 24, no. 2, pp. 285-307, June 1979.

[41] M. Koslowsky, A. N. Kluger, and M. Reich, Commuting Stress, Causes, Effects, and Methods of Coping, New York: Plenum Press, 1995.

[42] D. Applebaum, S. Fowler, N. Fiedler, O. Osinubi, and M. Robson, "The impact of environmental factors on nursing stress, job satisfaction, and turnover intention," Journal of Nursing Administration, vol. 40, no. 7/8, pp. 323-328, Aug. 2010.

[43] S. Cote and L. M. Morgan, "A longitudinal analysis of association between emotion regulation, job satisfaction and intentions to quit," Journal of Organizational Behavior, vol. 23, no. 8, pp. 947-962, Dec. 2002.

[44] M. Osmany and W. Khan, "Organizational stress in working women," Indian Psychological Review, vol. 61, pp. 2-6, Aug. 2003.

[45] Y. D. Foon, S. Osman et al., "An exploratory study on turnover intention among private sector employees," International Journal of Business and Management, vol. 5, no. 8, pp. 57-64, Sep. 2010.

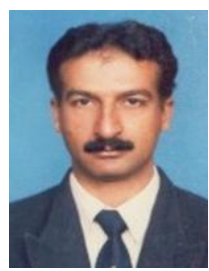

Ejaz Ahmed Khan was born on 13 March 1967, in Jhang Punjab Pakistan. He has completed his MSc Psychology degree in 1992 from the University of Punjab Lahore Pakistan, MA Political Science in 2010 from University of Sargodha Punjab Pakistan and MS I/O Psychology in 2011 from International Islamic University Islamabad Pakistan respectively. At presen he is a PhD Scholar at International Islamic University Islamabad. He is interested in I/O Psychology and my areas of interest are Organizational behavior, Job attitudes, Occupational Role Stressors, Work-family Conflict, Work-family Enrichment, Conflict Management, Organizational Politics, Group Dynamics, Political and Electoral Behavior $\mathrm{He}$ has presented his research articles in different conferences.

$\mathrm{He}$ is working as a lecturer in the Applied Department of Psychology at Govt Post Graduate College Jhang, Punjab Pakistan since 1996. He also a life time member of Pakistan Psychological Association.

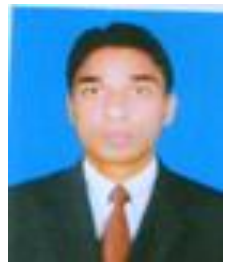

Muhammad Aqeel was born on 1986 in Toba Tek Singh Punjab Pakistan. He have completed my MSc Psycholoy degree in 2012 from Quaid-I-Azam University Islamabad Pakistan. Currently. He is doing MS in Clinical Psychology at International Islamic University Islamabad Pakistan. He has been trying to explore Antecedents and consequences of truancy in school children since last two years. He has skills regarding to latest software SPSS-20 R, Amose and M.Plus

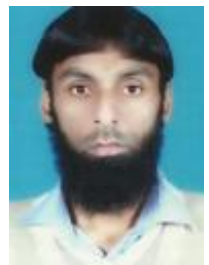

Muhammad Akram Riaz was born on 26 July 1985 in Sargodha Pakistan and recently. $\mathrm{He}$ is living in Islamabad. He has completed his master Psychology in 2012 from Quaid-I-Azam University Islamabad Pakistan. Recently he is doing MS Psychology from International Islamic university Islamabad Pakistan. He has skills in using SPSS for analyzing the data. He also is working as a visiting lecturer in the Department of Psychology, International Islamic University Islamabad. 